\title{
Comparison of treatments for congenital nonobstructive nonhaemolytic hyperbilirubinaemia
}

\author{
W. A. ARROWSMITH, R. B. PAYNE, and J. M. LITTLEWOOD \\ From Seacroft Hospital, Leeds, and the Department of Chemical Pathology, Leeds (St. James's) \\ University Hospital
}

\begin{abstract}
Arrowsmith, W. A., Payne, R. B., and Littlewood, J. M. (1975). Archives of Disease in Childhood, 50, 197. Comparison of treatments for congenital nonobstructive nonhaemolytic hyperbilirubinaemia. A patient with CriglerNajjar disease has survived with the help of phototherapy to the age of 2 years without neurological damage. Because long periods of phototherapy are a threat to normal development, a search was made for supplementary treatments. Cholestyramine and a high fat diet were effective, and possibly also aspartic acid. Maintenance therapy with cholestyramine allowed the amount of phototherapy given to be reduced.
\end{abstract}

Congenital nonobstructive nonhaemolytic hyperbilirubinaemia (Crigler-Najiar disease) is characterized by the presence of high levels of unconjugated bilirubin in the blood resulting from a congenital deficiency of glucuronyl transferase activity. To date some 86 cases have been published but this is an exaggerated figure as there has been some duplication of reporting. A full bibliography has been compiled by the authors and is available on request.

Arias et al. (1969) described two varieties of the disease, type I and type II. Those patients with type I are deeply jaundiced with serum unconjugated bilirubin levels of 17 to $40 \mathrm{mg} / 100 \mathrm{ml}$; they do not respond to treatment with phenobarbitone; they have no bilirubin glucuronide in their bile; inheritance appears to be in an autosomal recessive manner, and almost all have developed kernicterus. Those patients with type II have lower levels of bilirubin ranging from 4 to $20 \mathrm{mg} / 100 \mathrm{ml}$; they respond dramatically to treatment with phenobarbitone; they have normal levels of bilirubin glucuronide in their bile; inheritance is probably in an autosomal dominant manner, and most survive without neurological damage. Both types have very low levels of glucuronyl transferase activity in liver biopsy samples, with no significant difference between the two types. The cases originally described by Crigler and Najjar (1952) were probably all of Arias type I.
Treatment of Arias type I disease became possible with the advent of phototherapy and has prevented or delayed the development of kernicterus in many of the patients on which it has been used (Altay and Say, 1973; Béthenod et al., 1967; Callahan et al., 1970; Gorodischer et al., 1970; Götze et al., 1972; Karon, Imach, and Schwartz, 1970; Land, Zarkowsky, and Vietti, 1970; Nicola and Mussa, 1967; Salazar De Sousa, 1964).

In our patient phototherapy has succeeded in keeping serum bilirubin levels within safe limits, but it has also necessitated her remaining in hospital as she usually requires 20 hours of phototherapy each day. We are very much aware that her normal development may be impeded by this regimen and efforts have been made to provide her with as much normal stimulation as possible. Unfortunately, her parents have not found it possible to use a phototherapy unit at home. We have therefore sought methods of treatment which are less restricting, are simpler to administer, and might permit her return home.

\section{Case report}

The patient, a girl, was born on 3 December 1971 at a gestational age of 36 weeks after an uncomplicated pregnancy and labour. Her parents are Pakistani and unrelated. Mother was aged 31 years and had had 4 daughters, all healthy and unaffected by jaundice. She has had no miscarriages or stillbirths. There was no family history of jaundiced or brain-damaged children.

At birth our patient had a one-minute Apgar score of 10. She weighed $2183 \mathrm{~g}$. On initial physical examina- 
tion no abnormality was noted but the spleen was palpable to $\frac{1}{2} \mathrm{~cm}$ below the left costal margin.

Jaundice was first noticed at 16 hours of age and at that time her serum total bilirubin was $12.4 \mathrm{mg} / 100 \mathrm{ml}$, of which $0.6 \mathrm{mg}$ was conjugated. Treatment was started with continuous phototherapy using a Stanco blue light unit (Rank Precision Industries, Ltd.) containing $10 \times 60 \mathrm{~cm}$ tubes of 40 watts each. Exchange transfusion was performed on day 5 , but the jaundice persisted.

\section{Investigations}

Mother's blood group, O Rhesus positive. Baby's blood group, O Rhesus positive. Direct Coombs's test negative. Baby's blood film normal. Haemoglobin $13.8 \mathrm{~g} / \mathrm{dl}$ (8th day). White cell count $10500 / \mathrm{mm}^{3}$ (8th day). Glucose-6-phosphate dehydrogenase deficiency screening test negative. Pyruvate kinase activity $85 \mathrm{mU} / 10^{9}$ erythrocytes (normal 70-470). Red cell fragility curve normal. $X$-ray of knee, normal epiphyses. Protein-bound iodine $7 \cdot 2 \mu \mathrm{g} / 100 \mathrm{ml}$. Urine culture negative. Blood culture negative. Amino acid chromatogram showed increased quantities of leucine and isoleucine detected initially; normal when repeated. Sugar chromatogram of urine, none detected. Virus cultures of faeces, throat, and urine negative. Australia/ serum hepatitis antigen negative. Rubella haemagglutination inhibition titre, baby 1 in 128, mother 1 in 256. Cytomegalovirus complement fixation titre, baby 1 in 8. Toxoplasma dye test, baby 1 in 8 . Inhibitors of bilirubin conjugation in mother's serum, none detected (Dr. John Holton, Bristol). Urobilinogen in urine, no excess. Urobilinogen in faeces, none in 19 samples. Bilirubin in urine, none. Bilirubin in faeces, 2.94 $\mathrm{mg} /$ day (average of 15 consecutive days' samples at ages 6 and 7 weeks).

\section{Subsequent progress}

The patient is now aged 2 years. She has remained jaundiced with bilirubin levels ranging from 10 to 28 $\mathrm{mg} / 100 \mathrm{ml}$, being usually between 14 and $19 \mathrm{mg} / 100 \mathrm{ml}$. Despite prolonged hospitalization her mental and physical development have been well within normal limits.

\section{Treatment trials}

Our patient was given, in turn, aspartic acid, a high fat diet, phenobarbitone, uridine di-phosphoglucose, cholestyramine, and agar. Each of these treatments was given for a period of 3 weeks with intervals of at least 3 weeks between treatments. All other variables (e.g. amount of phototherapy, diet) were kept as constant as possible. Serum bilirubin concentrations were determined (by modification of the method of Powell, 1944) in duplicate, on venous blood, three times a week, care being taken to protect the blood samples from light during transit to the laboratory.

Aspartic acid. Both aspartic acid and orotic acid have been used for treating unconjugated hyperbilirubinaemia, and both substances have been shown to be effective in reducing neonatal jaundice (Kintzel, Hinkel, and Schwarze, 1971; Matsuda and Shirahata, 1966) though this has been disputed by Gray and Mowat (1971) and Mowat (1971). Aspartic acid is probably more effective than orotic acid (Matsuda and Shirahata, 1966), and as orotic acid has been associated with mortality in rats, it was not used on our patient. These substances have been used because they are precursors of uridine di-phosphoglucuronic acid which is a substrate in bilirubin conjugation. We used potassium L-aspartate in a dose of $300 \mathrm{mg}$ twice daily.

High fat diet. Housset et al. (1967) and Barrett (1971) have shown that a high fat diet reduces serum bilirubin levels in Gunn rats (rats having the equivalent of human Crigler-Najjar disease, Arias type I). The rationale is that fat-soluble unconjugated bilirubin which passes into the intestinal lumen other than in the bile (Lester, Hammaker, and Schmid, 1962), is held there if the intestinal contents are high in fat concentration. We increased the fat content of our patient's diet to an average of $66.9 \mathrm{~g} /$ day compared with $35 \mathrm{~g} /$ day before and after the treatment period.

Phenobarbitone. There is now much evidence that phenobarbitone is capable of inducing the enzyme glucuronyl transferase in normal persons. In patients with Arias type II Crigler-Najjar disease, phenobarbitone has been effective in reducing levels of unconjugated bilirubin (Arias et al., 1969; Arias, 1971; Crigler and Gold, 1969; Götze et al., 1972, Kreek and Sleisenger, 1968; Newton and Ertel, 1968). Phenobarbitone has had no effect, however, on the bilirubin levels of patients with Arias type I disease (Arias et al., 1969; Götze et al., 1972); indeed the response to phenobarbitone appears to be an effective method of determining whether the patient has Arias type I or type II disease.

Phenobarbitone $15 \mathrm{mg}$ daily was given to our patient in the neonatal period without obvious effect before we realized she had Crigler-Najiar disease. Subsequently two further treatment periods confirmed that the drug had no effect.

Uridine di-phosphoglucose (UDPG). UDPG has been used for the treatment of neonatal jaundice and has been shown to be effective in reducing bilirubin levels (Careddu and Marini, 1968; Marini, 1969). Unfortunately, UDPG is expensive and has to be given intramuscularly. We used UDPG $20 \mathrm{mg}$ twice daily and found no significant effect.

Cholestyramine. Cholestyramine has been successfully used to treat jaundice due to biliary atresia (Lottsfeldt et al., 1963), to cirrhosis in adults (Visintine et al., 1961), and in Gunn rats (Lester et al., 1962). Girotti et al. (1969), however, found no effect in a 5-day trial in one patient with presumed Crigler-Najjar disease; and both Nicola and Mussa (1967) and Blumenschein et al. (1968) found no effect in their patients with Crigler-Najiar disease, though dose and duration of treatment are not stated in the former. One of the 


\section{Comparison of treatments for congenital nonobstructive nonhaemolytic hyperbilirubinaemia 199}

patients described by Kreek and Sleisenger (1968) may have benefited from cholestyramine, though very little detail is given.

The rationale of its use is that, like fat, it holds bilirubin in the intestinal lumen (but by adsorption) and interrupts the enterohepatic circulation. We used cholestyramine in a dose of $\mathbf{2} \mathbf{g}$ twice daily.

Agar (Table). Agar, when fed to Gunn rats in laxative doses, has been shown to increase faecal bilirubin excretion, to improve growth rate, to lower mortality, and to protect partially against bilirubin nephropathy; and when given to neonates from age 20 hours for 4 days, bilirubin levels were lowered significantly (Poland and Odell, 1971). In addition, agar has been shown to reduce bilirubin levels in a patient with Crigler-Najjar disease (Poland, 1973).

The rationale for using agar is that it can interrupt the enterohepatic circulation of bilirubin by 'stabilizing it and preventing its bacterial conversion'.

Agar was given to our patient for 6 days at age 42 days without obvious effect. A further trial was undertaken at the age of 21 months. A number of preparations were examined for percentage inhibition of bacterial degradation by the patient's own bowel flora, using the method of Poland and Odell, (1971). The results in the Table show Oxoid No. 3 to be best, and this was used in a dose of $1 \mathrm{~g} / \mathrm{kg}$ body weight/day, but no significant effect was found.

\section{Results}

Interpretation of the effect of the various treatments given to our patient has been difficult because of the wide spontaneous variation she has shown in serum bilirubin concentration. For example, during the 2-month control period her bilirubin concentrations varied from about 12-20
TABLE

Per cent. bilirubin remaining after inhibition of degradation with various preparations of agar

\begin{tabular}{|c|c|c|c|c|c|}
\hline & \multicolumn{2}{|c|}{$\begin{array}{c}\text { Stool } \\
\text { collection } 1\end{array}$} & \multicolumn{2}{|c|}{$\stackrel{\text { Stool }}{\text { collection } 2}$} & \multirow{2}{*}{ Mean } \\
\hline & 1 & 2 & 1 & 2 & \\
\hline $\begin{array}{l}\text { Agar fibre } \\
\text { Agar fine powder } \\
\text { Agar New } \\
\text { Zealand coarse } \\
\text { Ionagar No. } 2 \\
\text { Agar shredded } \\
\text { Oxoid New Zealand } \\
\text { agar-agar } \\
\text { Oxoid No. } 3\end{array}$ & $\begin{array}{l}46 \\
65 \\
54 \\
73 \\
74 \\
58 \\
67\end{array}$ & $\begin{array}{l}47 \\
62 \\
\\
54 \\
73 \\
70 \\
\\
58 \\
66\end{array}$ & $\begin{array}{l}42 \\
41 \\
56 \\
46 \\
55 \\
72 \\
70\end{array}$ & $\begin{array}{l}39 \\
42 \\
-50 \\
55 \\
80 \\
73\end{array}$ & $\begin{array}{l}43 \cdot 5 \\
52 \cdot 5 \\
54 \cdot 7 \\
60 \cdot 5 \\
63 \cdot 5 \\
67 \cdot 0 \\
69 \cdot 0\end{array}$ \\
\hline
\end{tabular}

$\mathrm{mg} / 100 \mathrm{ml}$. For this reason we adopted a statistical approach. First we calculated the linear regression equation for bilirubin concentration on time and its correlation coefficient $(R)$ during each treatment and control period; then we calculated the probability that there was in fact a significant linear regression with time $\left(P_{1}\right)$; and finally we calculated the probability that the regression was significantly different from the change of bilirubin with time in the control period $\left(\mathbf{P}_{\mathbf{2}}\right)$.

In three treatment periods there was a statistically significant fall in serum bilirubin concentration with time-during treatment with aspartic acid, with a high fat diet, and with cholestyramine. It can be seen from the Fig. that the significance of the fall in bilirubin concentration during aspartic acid treatment $(0.05>P>0.02)$ depends largely on the last but one pair of bilirubin values. Spontaneous
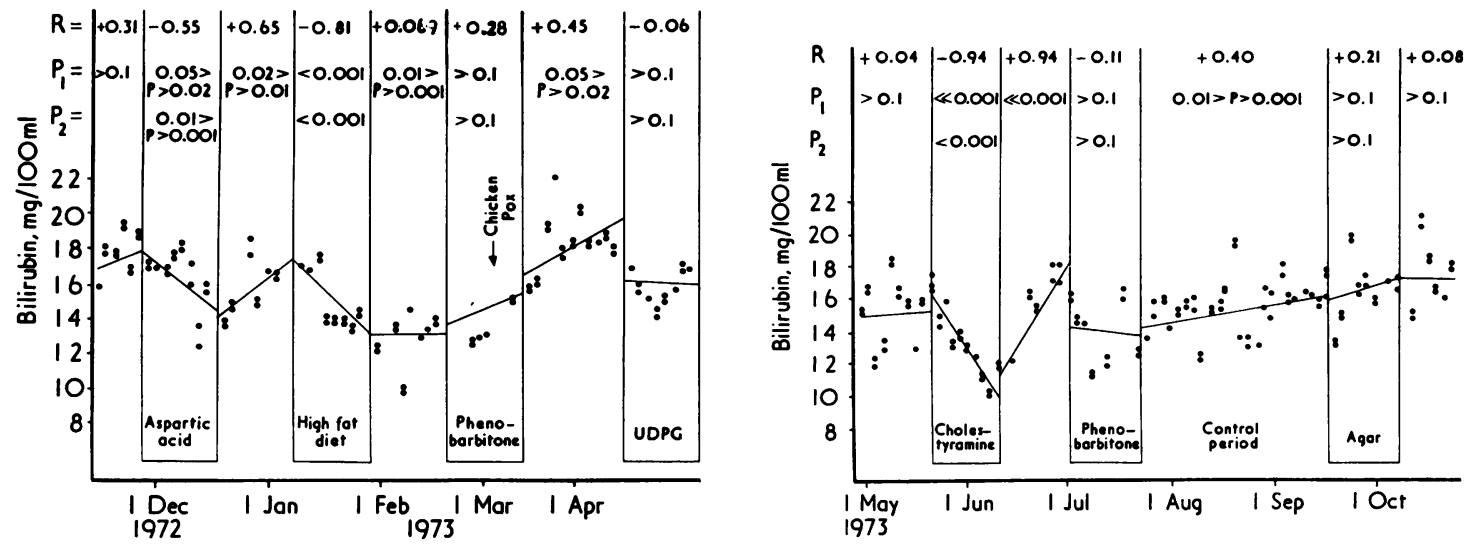

FIG.-Regressions of bilirubin with time. $R$, regression coefficient of bilirubin with time; $P_{1}$, significance of the correlation coefficient in each treatment period; $\mathbf{P}_{2}$, significance of the difference in regression coefficient between the treatment period and the control period. UDPG, uridine di-phosphoglucose. 
variation of this magnitude was seen during the control period, and, in spite of the statistical significance of the regression, interpretation is difficult. It is interesting that during treatment with a high fat diet there appeared to be an absolute fall of about $4 \mathrm{mg} / 100 \mathrm{ml}$ without any gradual progressive change, and analysis by linear regression is probably inappropriate. The most striking evidence of an effect of treatment is seen during the cholestyramine treatment period when there was a highly significant and convincing fall of serum bilirubin concentration with time $\left(P_{1}<0.001\right)$ of about $6.5 \mathrm{mg} / 100 \mathrm{ml}$, and a highly significant rise again in the following control period $\left(P_{1}<0.001\right)$.

\section{Discussion}

We found cholestyramine to be the most successful and most easily applied supplement to phototherapy. It has enabled us to reduce the amount of phototherapy given to our patient, allowing her greater freedom. Her bilirubin values over some 4 months of continuous treatment with cholestyramine are significantly lower (mean $12 \cdot 3$, SD $2 \cdot 0$ ) than in the 8-week control period (mean 15.5, SD $1.6 ; \mathrm{P}<0.001)$ despite this greater freedom and reduction in phototherapy time. A recent attempt to repeat the treatment trial with cholestyramine was abandoned because the bilirubin level rose to over $20 \mathrm{mg} / 100 \mathrm{ml}$ within 10 days of stopping the drug.

In view of the known possible complications of long-term cholestyramine therapy, she has vitamin supplements and her alkaline phosphatase levels and prothrombin time are checked periodically. She has started going home during the daytime (at present only 2 days each week) to return in the evening to hospital to sleep under the phototherapy unit. Her present bilirubin levels range from $9 \cdot 0$ to $14.0 \mathrm{mg} / 100 \mathrm{ml}$ despite her days at home. We look forward to her being able to stay at home every day, probably sleeping each night at the hospital for phototherapy and occasional checks on bilirubin levels.

We are grateful to Professor G. H. Lathe, Department of Chemical Pathology, University of Leeds, for many helpful suggestions; to Mr. C. H. Ramsden, Department of Bacteriology and Mr. K. R. Johnson, Department of Chemical Pathology, Leeds (St. James's) University Hospital for examining specimens of agar for percentage inhibition of bacterial degradation of bilirubin; to Dr. John Holton of Southmead Hospital, Bristol, for looking for inhibitors of bilirubin conjugation in the mother's serum; to the nursing staff at Seacroft Hospital for their enthusiastic care of the patient; and to Rank Precision Industries, Ltd. for provision of a phototherapy unit.

\section{REFERENCES}

Altay, C., and Say, B. (1973). Phototherapy in nonobstructive nonhemolytic jaundice. Pediatrics, 51, 124.

Arias, I. M. (1971). Inheritable and congenital hyperbilirubinemia: models for the study of drug metabolism. New England Fournal of Medicine, 285, 1416.

Arias, I. M., Gartner, L. M., Cohen, M., Ben-Ezzer, J., and Levi, A. J. (1969). Chronic nonhemolytic unconjugated hyperbilirubinemia with glucuronyltransferase deficiency. Clinical, biochemical, pharmacologic, and genetic evidence for heterogeneity. American fournal of Medicine, 47, 395.

Barrett, P. V. D. (1971). The effect of diet and fasting on the serum bilirubin concentration in the rat. Gastroenterology, 60, 572.

Béthenod, M., André, J. P., Cotte, J., Mathieu, M., Collombel, C., Cotte, M. F., and Nivelon, J. L. (1967). La photothérapie dans la maladie de Crigler et Najjar; intérêt et limites. Annales de Pédiatrie, 14, 829.

Blumenschein, S. D., Kallen, R. J., Storey, B., Natzschka, J. C., Odell, G. B., and Childs, B. (1968). Familial nonhemolytic jaundice with late onset of neurological damage. Pediatrics, 42, 786.

Callahan, E. W., Thaler, M. M., Karon, M., and Schmid, R. (1970). Phototherapy in congenital nonhemolytic jaundice. Kinetics of bilirubin metabolism and disposition of labelled degradation products. Pediatrics, 46, 841 .

Careddu, P., and Marini, A. (1968). Stimulating bilirubin conjugation. Lancet, 1, 982.

Crigler, J. F., Jr., and Gold, N. I. (1969). Effect of sodium phenobarbital on bilirubin metabolism in an infant with congenital, nonhemolytic, unconjugated hyperbilirubinemia and kernicterus. Fournal of Clinical Investigation, 48, 42.

Crigler, J. F., Jr., and Najjar, V. A. (1952). Congenital familial nonhemolytic jaundice with kernicterus. Pediatrics, 10, 169.

Girotti, F., Finocchi, G., Sartori, L., and Boscherini, B. (1969). Congenital nonhaemolytic jaundice in a four-years-old girl without disease of the central nervous system. Helvetica Paediatrica Acta, 24, 399.

Gorodischer, R., Levy, G., Krasner, J., and Yaffe, S. J. (1970). Congenital nonobstructive nonhemolytic jaundice. Effect of phototherapy. New England fournal of Medicine, 282, 375.

Götze, H., Sidiropoulos, D., Hess, F. A., und Berthelot, P. (1972). Das Crigler-Najiar Syndrome: Klinische, biochemische, morphologische und therapeutische Aspekte. Helvetica Paediatric Acta, 27, 335.

Gray, D. W. G., and Mowat, A. P. (1971). Effects of aspartic acid, orotic acid, and glucose on serum bilirubin concentrations in infants born before term. Archives of Disease in Childhood, 46, 123.

Housset, E., Etienne, J. P., Petite, J. P., Oudéa, P., Audéa, M. C., and Manchon, P. (1967). Rôle du régime alimentaire sur la bilirubinémie du rat Gunn. Applications expérimentalles: cholépéritoines, cholostases, action de la novobiocine. Pathologie et Biologie, 15, 457.

Karon, M., Imach, D., and Schwartz, A. (1970). Effective phototherapy in congenital nonobstructive, nonhemolytic jaundice. New England Fournal of Medicine, 282, 377.

Kintzel, H. W., Hinkel, G. K., and Schwarze, R. (1971). The decrease in the serum bilirubin level in premature infants by orotic acid. Acta Paediatrica Scandinavica, 60, 1.

Kreek, M. J., and Sleisenger, M. H. (1968). Reduction of serumunconjugated-bilirubin with phenobarbitone in adult congenital nonhaemolytic unconjugated hyperbilirubinaemia. Lancet, 2, 73.

Land, V. J., Zarkowsky, H. S., and Vietti, T. J. (1970). Phototherapy for jaundice. New England fournal of Medicine, 282, 397.

Lester, R., Hammaker, L., and Schmid, R. (1962). A new therapeutic approach to unconjugated hyperbilirubinaemia. Lancet, 2, 1257 .

Lottsfeldt, F. I., Krivit, W., Aust, J. B., and Carey, J. B. (1963). Cholestyramine therapy in intrahepatic biliary atresia. New England fournal of Medicine, 269, 186.

Marini, A. (1969). Blood bilirubin responsiveness to uridine di-phosphoglucose in the newborn infant. Minerva Pediatrica, 21, 1386.

Matsuda, I., and Shirahata, T. (1966). Effects of aspartic acid and orotic acid upon serum bilirubin levels in newborn infants. Tohoku fournal of Experimental Medicine, 90, 133. 
Mowat, A. (1971). Double-blind trial of effects of aspartic acid, orotic acid and glucose on serum bilirubin concentrations in infants born before term. (Abstr.) Archives of Disease in Childhood, 46, 397.

Newton, W. A., and Ertel, I. J. (1968). Phenobarbital in the treatment of hyperbilirubinemia in the Crigler-Najiar syndrome. Fournal of Pediatrics, 72, 586.

Nicola, P., and Mussa, G. C. (1967). Ittero familiare non emolitico con ittero nucleare o mallattia di Crigler e Najiar. Minerva Pediatrica, 19, 1349.

Poland, R. L. (1973). Spring, 1972, Meeting of Pediatric Societies, Washington. 1973 Year Book of Pediatrics, p. 21. Ed. by S. S. Gellis. Year Book Medical Publishers, Chicago.

Poland, R. L., and Odell, G. B. (1971). Physiologic jaundice: the enterohepatic circulation of bilirubin. New England fournal of Medicine, 284, 1.

Powell, W. N. (1944). A method for the quantitative determination of serum bilirubin with the photo-electric colorimeter. American fournal of Clinical Pathology, (Technical Section), 14, 55.

Salazar De Sousa, C. (1964). A case of Crigler-Najiar's Disease treated by light irradiation. Clinica Pediatrica, 46, 797.

Visintine, R. E., Michaels, G. D., Fukayama, G., Conklin, J., and Kinsell, L. W. (1961). Xanthomatous biliary cirrhosis treated with cholestyramine: a bile-acid adsorbing resin. Lancet, 2, 341 .

Correspondence to Dr J. M. Littlewood, Seacroft Hospital, York Road, Leeds LS14 6UH. 